\title{
The Educational and Social Profile of the Indigenous People of Ecuador: A Multidimensional Analysis
}

\author{
José Manuel Castellano ${ }^{1}$, Efstathios Stefos ${ }^{1} \&$ Lisa Gaye Williams Goodrich ${ }^{1}$ \\ ${ }^{1}$ National University of Education (UNAE), Azogues, Ecuador \\ Correspondence: Efstathios Stefos, National University of Education (UNAE), Azogues, Cañar, Parroquia Javier \\ Loyola (sector Chuquipata), Ecuador. Tel: 593-7-370-1200. E-mail: estefos@aegean.gr
}

Received: November 17, 2016

Accepted: November 23, $2016 \quad$ Online Published: January 10, 2017

doi:10.5539/res.v9n1p137

URL: http://dx.doi.org/10.5539/res.v9n1p137

\begin{abstract}
The objective of the study is to examine the educational level and the social profile of the indigenous people of Ecuador by means of a descriptive and multidimensional statistical analysis of this sector of the Ecuadorian population, based on data from the National Survey of Employment, Unemployment and Underemployment from 2015. The descriptive analysis shows the frequency and percentages of the variables used in the investigation, while the multidimensional statistical analysis is used in order to show the principal and most important criteria of differentiation and classification among the groups of people investigated. These methods involve a factorial analysis of multiple correspondences which demostrates the criteria of differentiation and a hierarchical cluster analysis to define groups of people according to their common traits.
\end{abstract}

Keywords: indigenous peoples, Ecuador, multidimensional statistical analysis

\section{Introduction}

From last third of the twentieth century, the implementation of policies addressing the extension of specific literacy programs and campaigns in Ecuador have resulted in the reduction of illiteracy throughout the country. The progress towards the universal provision of education along with the economic growth of Ecuador in the last decade of the twentieth century, have facilitated the transformation of the Ecuadorian society not only in terms of education but also in terms of social development strategies. Nevertheless, in the following decades, and despite a continuous descent in the number of illiterate Ecuadorians, there is still a high level of illiteracy among Ecuadorians of indigenous and African descent compared to the level of illiteracy among the mestizo population. In fact, as Ponce (2003) and Torres (2005) have shown in their respective studies, even during the first few years of the twenty first century, elevated rates of illiteracy among Indigenous peoples and Afro-Ecuadorians continued to exist despite these efforts on the part of the Ecuadorian government to reduce illiteracy in the general population.

Broadly speaking, the Republic of Ecuador is a multi-ethnic, multi-cultural country made up of diverse indigenous nationalities, mestizos and Ecuadorians of African descent. Nevertheless, given the scope of this study, this article will only be looking at the social and educational transformation of the indigenous peoples of Ecuador.

In this respect, the indigenous peoples are concentrated mainly in three specific regions of the country: the coast, the mountain and the Amazon, where diverse indigenous nationalities with their respective native languages coexist. The Kichwa indigenous community is the largest ethnic group in Ecuador (32.23\%), followed by the Puruha $(13.37 \%)$, the Shuar (7.83\%), the Panzaleo (5.99\%), the Otavalo $(5.57 \%)$, the Kayambi $(3.31 \%)$ and the Kañari $(2.1 \%)$, the Saraguro $(1.68 \%)$, the Waranka $(1.67 \%)$, the Tomabela $(1.18 \%)$, the Karanki $(1.14 \%)$, the Chachi $(1.00 \%)$, the Kisapincha $(0.99 \%)$, the Achuar $(0.77 \%)$, the Andoa $(0.63 \%)$, the Awa $(0.54 \%)$, the Chibuleo $(0.53 \%)$, the Tsachila $(0.29 \%)$, the Waorani $(0.24 \%)$, the Kitukara $(0.24 \%)$, the Huancavilca $(0.05 \%)$, the Pala $(0.04 \%)$, the Manta $(0.05 \%)$, the Cofan $(0.15 \%)$, the Pastos $(0.14 \%)$, the Shiwiar $(0.12 \%)$, the Secoya $(0.07 \%)$, the Siona $(0.03 \%)$ and other smaller indigenous communities (Stefos, 2015).

The objective of this study is to analyze the social profile and education level of the indigenous peoples of Ecuador, who, according to the last national census, ascended to 1018176 , a figure which represents $7.02 \%$ of the population of Ecuador (INEC, 2010). 


\section{Method}

The study uses as reference statistical information from the 2015 National Survey of Employment, Unemployment and Underemployment (INEC, 2015). Given the objective of the present study, a descriptive and a multidimensional statistical analysis were done, with the former showing the frequency and percentages of the variables under investigation (Athanasiadis, 1995).

The multidimensional statistical analysis, on the other hand, is used to illustrate the principal and most important criteria of differentiation and the classification of the sample population into groups. This included utilizing factorial and hierarchical analyses to reveal the differences between and, in the case of hierarchical analysis, investigate the correlation between the variables of the survey.

In other words, the factorial axes are the criteria of differentiation which elucidate the opposing points in the answer of the subjects, while the hierarchical analysis shows the clusters of people according to their replies and common traits. This method also presents a graph of the classification that connects these clusters (Papapostolou et al., 2013). SPAD v 4.5 software offered by the Faculty of Humanities of the University of the Aegean was used to analyse the data.

\section{Descriptive Analysis}

A small percentage of the indigenous population sampled live in the urban area $(15.99 \%)$ while the vast majority $(84.01 \%)$ live in rural areas (Table 1$)$.

Table 1. Area

\begin{tabular}{lcc}
\hline & $\mathrm{N}$ & $\%$ \\
\hline Urban & 2251 & $15.99 \%$ \\
Rural & 11825 & $84.01 \%$ \\
Total & 14076 & $100.00 \%$ \\
\hline
\end{tabular}

The number of men and women surveyed was basically similar, although the percentage of women surpassed that of the men by $2.66 \%$ (Table 2 ).

Table 2. Sex

\begin{tabular}{lcc}
\hline & $\mathrm{n}$ & $\%$ \\
\hline Male & 6851 & $48.67 \%$ \\
Female & 7225 & $51.33 \%$ \\
Total & 14076 & $100.00 \%$ \\
\hline
\end{tabular}

The predominant age group in the survey was between 10 to 20 years of age $(28.84 \%)$, followed by the age group of 0 to $10(15.78 \%)$, bringing the number of subjects under the age of 20 to over $40 \%$ of the sample population (Table 3 ).

Table 3. Age

\begin{tabular}{lcc}
\hline & $\mathrm{n}$ & $\%$ \\
\hline 0 to 10 & 2221 & $15.78 \%$ \\
10 to 20 & 4060 & $28.84 \%$ \\
20 to 30 & 2206 & $15.67 \%$ \\
30 to 40 & 1886 & $13.40 \%$ \\
$40-50$ & 1386 & $9.85 \%$ \\
50 to 60 & 960 & $6.82 \%$ \\
\hline
\end{tabular}




\begin{tabular}{lcc}
\hline 60 to 70 & 729 & $5.18 \%$ \\
70 to 80 & 440 & $3.13 \%$ \\
80 to 90 & 162 & $1.15 \%$ \\
90 to 98 & 24 & $0.17 \%$ \\
98 and older & 2 & $0.01 \%$ \\
Total & 14076 & $100.00 \%$ \\
\hline
\end{tabular}

According to the data collected there are roughly as many married subjects $(31.54 \%)$ as there are single ones (30.06\%), however a little more than $40 \%$ of the sample population are in some sort of union with a very small percentage of the surveyed are separated $(1.71 \%)$ or divorced $(0.55 \%)$. Nevertheless, as high as one fifth of the population do not find any of the categories of marital status used in the survey to be applicable to them, likely due to the fact that more or less $15 \%$ of the subjects in this study are under 10 years old and a little less than a third of the population surveyed between the ages of 10 and 20 (Table 4).

Table 4. Marital status

\begin{tabular}{lcc}
\hline & $\mathrm{n}$ & $\%$ \\
\hline Married & 4439 & $31.54 \%$ \\
Separated & 240 & $1.71 \%$ \\
Divorced & 77 & $0.55 \%$ \\
Widowed & 437 & $3.10 \%$ \\
Common Law Union & 1514 & $10.76 \%$ \\
Single & 4231 & $30.06 \%$ \\
NA & 3138 & $22.29 \%$ \\
Total & 14076 & $100.00 \%$ \\
\hline
\end{tabular}

With regards to the education level of the indigenous Ecuadorians, roughly $40 \%$ of the surveyed population have a basic education, followed by $24.42 \%$ who only have a primary education level. Half the percentage of this group have been able to achieve a middle education level (12.77\%) and practically the same number of subjects who have a secondary education level $(9.21 \%)$ have had no formal academic formation $(9.22 \%)$. Given these statistics, expectedly, only a minimal percentage of the indigenous population have a university degree or a higher education level $(2.8 \%)$, with an understandably even lower percentage, as low as $0.12 \%$, going on to post-graduate studies (Table 5).

Table 5. Education level

\begin{tabular}{lcc}
\hline & $\mathrm{n}$ & $\%$ \\
\hline None & 1298 & $9.22 \%$ \\
Literacy Center & 167 & $1.19 \%$ \\
Primary & 3437 & $24.42 \%$ \\
Basic Education & 5556 & $39.47 \%$ \\
Middle Education & 1798 & $12.77 \%$ \\
Secondary Education & 1297 & $9.21 \%$ \\
Cycle Post-Baccalaureate & 112 & $0.80 \%$ \\
Higher Education & 394 & $2.80 \%$ \\
Post-graduate studies & 17 & $0.12 \%$ \\
Total & 14076 & $100.00 \%$ \\
\hline
\end{tabular}


As far as language is concerned, close to $70 \%$ of the population is bilingual (speak both an indigenous language and Spanish), although the percentage of those who only speak Spanish (28.57\%) is much higher than those who only speak an indigenous language (2.10\%). Very few speak any other language but Spanish and an indigenous language $(0.35 \%)$, and almost none of the surveyed population spoke both an indigenous and a foreign language $(0.02 \%)$. Conversely, there is a sector of the population, albeit very small, who apparently lack the ability to speak $(0.28 \%)$ (Table 6$)$.

Table 6. Languages spoken

\begin{tabular}{lcc}
\hline & $\mathrm{n}$ & $\%$ \\
\hline Only indigenous language & 295 & $2.10 \%$ \\
Indigenous language and Spanish & 9650 & $68.56 \%$ \\
Only Spanish & 4022 & $28.57 \%$ \\
Spanish and a foreign language & 18 & $0.13 \%$ \\
Indigenous and a foreign language & 3 & $0.02 \%$ \\
Foreign language & 49 & $0.35 \%$ \\
Does not speak & 39 & $0.28 \%$ \\
Total & 14076 & $100.00 \%$ \\
\hline
\end{tabular}

Regarding the status of inactivity, roughly a third of the surveyed population classify themselves as students, although close $60 \%$, do not find any of the categories (landlord, pensioner, student, housewife, disabled and other) applicable to their status. The third largest group, although a small number $(6.07 \%)$, is represented by housewives (Table 7).

Table 7. Status of inactivity

\begin{tabular}{lcc}
\hline & $\mathrm{n}$ & $\%$ \\
\hline Landlord & 10 & $0.07 \%$ \\
Pensioner & 39 & $0.28 \%$ \\
Student & 4441 & $31.55 \%$ \\
Housewife & 855 & $6.07 \%$ \\
Disabled & 286 & $2.03 \%$ \\
Other & 126 & $0.90 \%$ \\
NA & 8319 & $59.10 \%$ \\
Total & 14076 & $100.00 \%$ \\
\hline
\end{tabular}

In terms of happiness on the job, 37.94\% of the sample population claimed to be happy with their jobs, with a much smaller percentage (8.43\%) stating the contrary ("not very happy") and an almost insignificant percent of the population, comparatively speaking, claiming to be "completely unhappy" with their jobs $(0.96 \%)$. The percentage of relatively unhappy workers, however, doubles that of those who are unhappy but conformant at work $(4.31 \%)$. Nevertheless, it should be noted that the highest percentage $(48.36 \%)$ came from the "not applicable" category, which may represent those indigenous people who are either ambivalent about their level of happiness at work or may simply involve subjects who are unemployed (over $40 \%$ of the population under study is under 20 years old) or have no steady employment (Table 8). 
Table 8. The level of happiness at work

\begin{tabular}{lcc}
\hline & $\mathrm{n}$ & $\%$ \\
\hline Happy & 5341 & $37.94 \%$ \\
Not very happy & 1186 & $8.43 \%$ \\
Unhappy but conformant & 607 & $4.31 \%$ \\
Completely unhappy & 135 & $0.96 \%$ \\
NA & 6807 & $48.36 \%$ \\
Total & 14076 & $100.00 \%$ \\
\hline
\end{tabular}

With relation to cellular phone usage, close to $70 \%$ of the surveyed subjects did not own an activated mobile phone (Table 9). On the other hand, although roughly $30 \%$ of the population owned a cellular phone, less than $5 \%$ actually owned a smartphone (Table 10 ).

Table 9. Has an activated cellular phone

\begin{tabular}{lcc}
\hline & $\mathrm{n}$ & $\%$ \\
\hline Yes & 4337 & $30.81 \%$ \\
No & 9609 & $68.27 \%$ \\
NA & 130 & $0.92 \%$ \\
Total & 14076 & $100.00 \%$ \\
\hline
\end{tabular}

Table 10. Telephone is a smartphone

\begin{tabular}{lcc}
\hline & $\mathrm{n}$ & $\%$ \\
\hline Yes & 683 & $4.85 \%$ \\
No & 3654 & $25.96 \%$ \\
NA & 9739 & $69.19 \%$ \\
Total & 14076 & $100.00 \%$ \\
\hline
\end{tabular}

Nevertheless, over $30 \%$ of the population have had access to the Internet over the past 12 months, which somewhat coincides with the percentage of subjects who have used a computer $(35.49 \%)$ in the past year (Table 11, Table 12).

Table 11. Has used a computer in the past 12 months

\begin{tabular}{ccc}
\hline & $\mathrm{n}$ & $\%$ \\
\hline Yes & 4995 & $35.49 \%$ \\
No & 8951 & $63.59 \%$ \\
NA & 130 & $0.92 \%$ \\
Total & 14076 & $100.00 \%$ \\
\hline
\end{tabular}

Table 12. Has used the Internet in the past 12 months

\begin{tabular}{ccc}
\hline & $\mathrm{n}$ & $\%$ \\
\hline Yes & 4582 & $32.55 \%$ \\
No & 9364 & $66.52 \%$ \\
NA & 130 & $0.92 \%$ \\
Total & 14076 & $100.00 \%$ \\
\hline
\end{tabular}


There is still a very high percentage of the population sampled, roughly $60 \%$, who have not got cellular phones, used a computer or accessed the Internet during the past 12 months.

Almost half of the subjects in this investigation (49\%) are from the mountain region of Ecuador followed closely behind by the subjects from the Amazon region (47.72\%). The coastal region is underrepresented in this sample with only a mere $3.17 \%$ constituting the indigenous population (Table 13 ).

Table 13. Region

\begin{tabular}{ccc}
\hline & $\mathrm{n}$ & $\%$ \\
\hline Mountain Region & 6897 & $49.00 \%$ \\
Coastal Region & 438 & $3.11 \%$ \\
Amazon Region & 6717 & $47.72 \%$ \\
Insular Region & 24 & $0.17 \%$ \\
Total & 14076 & $100.00 \%$ \\
\hline
\end{tabular}

With regards to the type of economic activity engaged in, $35.12 \%$ of the population work in either agriculture, livestock farming, hunting, forestry or fishing, which are not precisely activities associated with hours in front of a computer or which would necessarily involve needing to have access to the Internet. The highest percentage of the population sample, however, fall into the "not applicable" category $(48.15 \%)$ with regard to the activities listed, almost the same amount as the number of people for whom the level of happiness at the workplace did not seem to apply. According to the statistical data, there is a great disparity between the percentage of people engaged in work related outdoor activities as opposed to those working in construction (3.87\%), manufacturing industries $(2.34 \%)$, public administration $(1.3 \%)$ or teaching $(1.31 \%)$, with under one percent involved in utilities related services such as gas, electricity and water supply $(0.04 \%)$, information and communication $(0.18 \%)$ and financial and insurance services $(0.18 \%)$ (Table 14$)$.

Table 14. Type of activity

\begin{tabular}{lcc}
\hline & $\mathrm{n}$ & $\%$ \\
\hline Agriculture, livestock farming, hunting, forestry and fishing & 4944 & $35.12 \%$ \\
Mining and quarrying & 43 & $0.31 \%$ \\
Manufacturing industries & 329 & $2.34 \%$ \\
Gas, electricity and air-conditioning supply & 5 & $0.04 \%$ \\
Distribution of water and drainage & 8 & $0.06 \%$ \\
Construction & 545 & $3.87 \%$ \\
Commerce and vehicle repair & 465 & $3.30 \%$ \\
Transport and storage & 114 & $0.81 \%$ \\
Accomodation and food services & 157 & $1.12 \%$ \\
Information and communication & 25 & $0.18 \%$ \\
Financial and insurance activities & 25 & $0.18 \%$ \\
Profesional, scientific and technical activities & 12 & $0.09 \%$ \\
Administrative services and support & 49 & $0.35 \%$ \\
Public administration, defense and social security & 183 & $1.30 \%$ \\
Teaching & 185 & $1.31 \%$ \\
Social services and health & 56 & $0.40 \%$ \\
Arts, entertainment and recreation & 14 & $0.10 \%$ \\
Other service activities & 63 & $0.45 \%$ \\
Activites in private homes with domestic service & 76 & $0.54 \%$ \\
NA & 6778 & $48.15 \%$ \\
Total & 14076 & $100.00 \%$ \\
\hline
\end{tabular}


A little more than half the population (55.24\%) is considered to be poor although this percentage does not differ greatly from those who are not considered to be poor (43.96\%) (Table 15$)$.

Table 15 . Income poverty

\begin{tabular}{ccc}
\hline & $\mathrm{n}$ & $\%$ \\
\hline Not poor & 6188 & $43.96 \%$ \\
Poor & 7776 & $55.24 \%$ \\
NA & 112 & $0.80 \%$ \\
Total & 14076 & $100.00 \%$ \\
\hline
\end{tabular}

Despite the high percentage of poor subjects, however, only $32.94 \%$ of the population is classified as indigent (Table 16).

Table 16. Extreme income poverty

\begin{tabular}{ccc}
\hline & $\mathrm{n}$ & $\%$ \\
\hline Not indigent & 9327 & $66.26 \%$ \\
Indigent & 4637 & $32.94 \%$ \\
NA & 112 & $0.80 \%$ \\
Total & 14076 & $100.00 \%$ \\
\hline
\end{tabular}

In measuring the status of activity, the investigation determined that roughly $18 \%$ of the population regarded their job as unsuitable, while $15 \%$ were in the category of unpaid employment. Conversely, a similar percentage $(15.42 \%)$ was found to represent economically inactive people. Nevertheless, a relatively high percentage $(31.44 \%)$ of the sample population are under 15 years of age, which could account for the high percentage $(48.15 \%)$ of those who do not identify with any type of activity in the survey (Table 17$)$.

Table 17. Activity status

\begin{tabular}{lcc}
\hline & $\mathrm{n}$ & $\%$ \\
\hline Suitable job & 1507 & $10.71 \%$ \\
Underemployment due to insufficient work time & 799 & $5.68 \%$ \\
Underemployment due to insufficient income & 215 & $1.53 \%$ \\
Other unsuitable employment & 2636 & $18.73 \%$ \\
Unpaid employment & 2131 & $15.14 \%$ \\
Unclassified employment & 10 & $0.07 \%$ \\
Open unemployment & 116 & $0.82 \%$ \\
Hidden unemployment & 66 & $0.47 \%$ \\
Economically inactive population & 2170 & $15.42 \%$ \\
Under 15 years old & 4426 & $31.44 \%$ \\
Total & 14076 & $100.00 \%$ \\
\hline
\end{tabular}

\section{Factorial Analysis of Multiple Correspondence}

The method of factorial analysis of multiple correspondence was utilized with the objective of revealing how the subjects of the survey differ according to their answers (Stefos \& Koulianidi, 2016). The criteria which differentiate the surveyed subjects are: 


\subsection{The First Criterion of Differentiation (Percentage of Inertia 14.39\%)}

With regard to the first axis, there are indigenous peoples who are married, content with their jobs, work in agriculture and livestock farming, have a cellular telephone and a primary school educational level. On the other hand, there is a portion of the indigenous population under 15 years, who are students of basic education and who do not have cellular phones but who, over the past twelve months, have used a computer or the Internet.

\subsection{The Second Criterion of the Differentiation (Percentage of Inertia 8.06\%)}

With relation to the second axis, there are poor indigenous people and indigents, who do not have any academic formation, live in rural areas, work in agriculture and livestock farming, they have no cellular telephone and have not used a computer or the Internet in the past 12 months. At the same time, however, there are indigenous single men who are not considered poor, whose education level is middle education or higher, who own smartphones and have used a computer or the Internet in the past twelve months.

\subsection{The Third Criterion of Differentiation (Percentage of Inertia 5.80\%)}

Regarding the third axis, there exist indigenous housewives, disabled and widowed individuals who are not considered to be poor, who only speak their indigenous language and who live in the mountain region. In contrast, there are indigenous people who may be classified as poor and indigent, who work in agriculture and livestock farming and who live in the rural area of the Amazon region.

\section{Hierarchical Analysis}

The hierarchical analysis consists of seven groups of indigenous people as illustrated in the chart below (Benzécri, 1992).

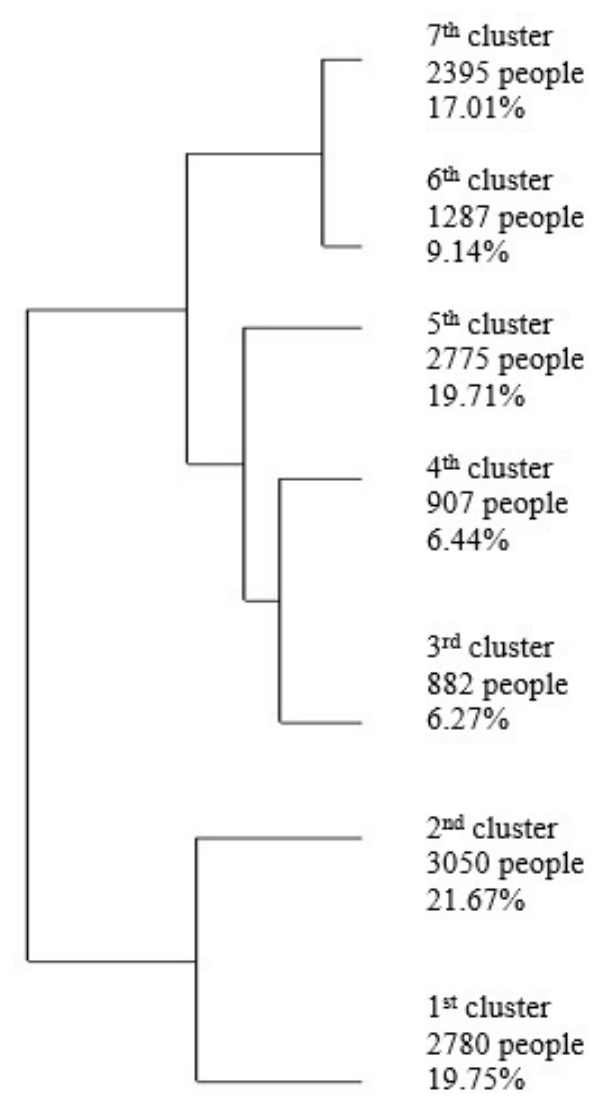

Figure 1. Chart of the classified groups 


\subsection{First Cluster (2780 People, 19.75\% of the Sample)}

The indigenous people of the first cluster are under 10 years old, attend basic school, speak only Spanish and are considered to be poor. They do not have a cellular phone nor have they used a computer or the Internet in the past 12 months.

\subsection{Second Cluster (3050 People, 21.67\% of the Sample)}

The indigenous subjects of the second cluster are students between the ages of 10 and 20, the majority of whom are therefore single. However, as opposed to the first group, the subjects of this group have used the computer or the Internet during the past 12 months.

\subsection{Third Cluster (882 People, 6.27\% of the Sample)}

The indigenous population of this cluster are housewives who are either married or in common-law unions. Their academic formation only go up until primary school level and unlike the second cluster, have not utilized a computer or the Internet during the course of the past 12 months.

\subsection{Fourth Cluster (907 People, 6.44\% of the Sample)}

The indigenous people of the fourth cluster, on the other hand, have not received any formal schooling, speak no other language than their native indigenous tongue, are older than 60 , widowed and/or disabled and for the most part live in the mountain region of Ecuador.

\subsection{Fifth Cluster (2775 People, 19.71\% of the Sample)}

The fifth cluster is made up of indigenous peoples who have received more than a primary school education and who either work in agriculture and livestock farming or involved in another sort of unpaid or unsalaried laboral activity. According to the study, for the past 12 months, this group has not used a computer or accessed the Internet.

\subsection{Sixth Cluster (1287 People, 9.14\% of the Sample)}

This sixth cluster of indigenous people, on the other hand, own smartphones and have used the computer and the Internet over the past 12 months. They have up to a secondary school education (in some cases, a superior level) and have declared themselves to be satisfied with their jobs.

\subsection{Seventh Cluster (2395 People, 17.01\% of the Sample)}

The seventh cluster consists of indigenous people who are married and have cellular phones but who have not accessed the Internet or used a computer in the past 12 months. They have a primary school level of education and have indicated that they do not find their jobs suitable.

The differences between these clusters can be seen in Figure 2 where the Correspondence Analysis (factorial levels $1 \times 2$ ) graph presents the centroids of the 7 clusters in the two axes. Additionally, it defines the differences and similarities between the subjects of these seven clusters (Stefos \& Papapostolou, 2013).

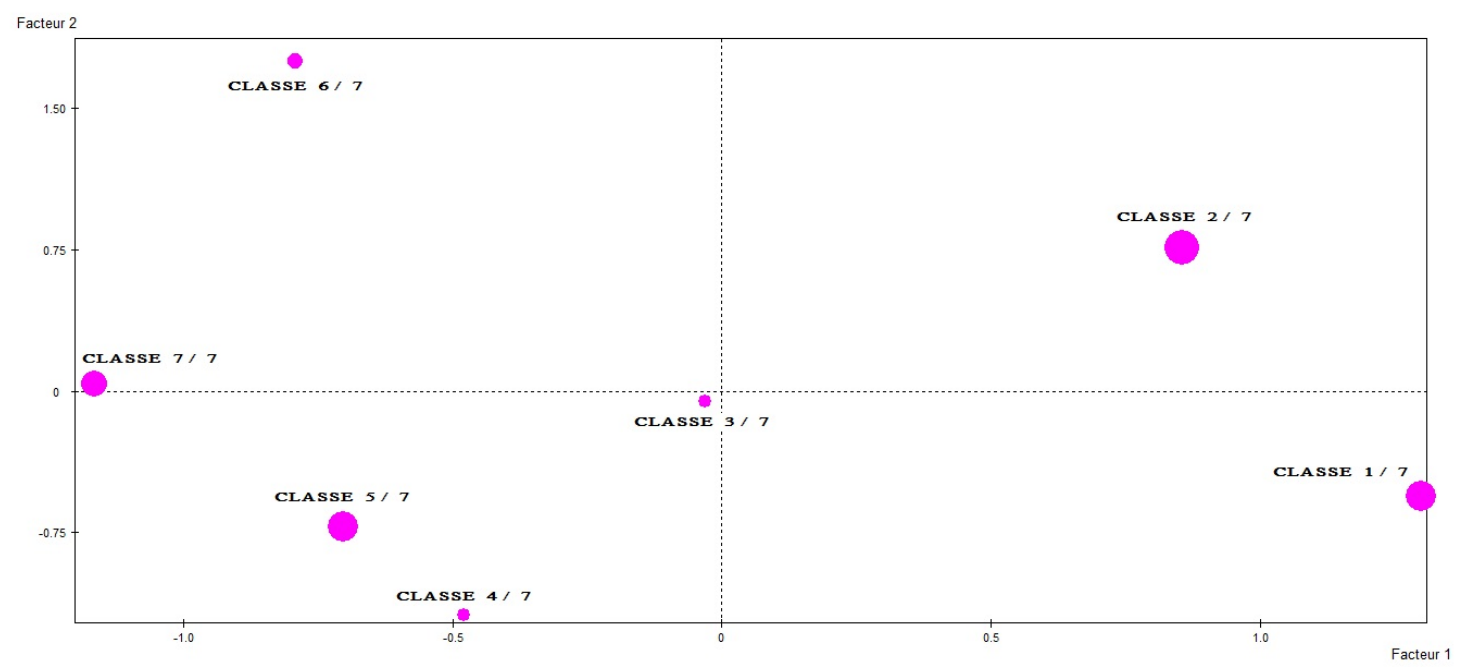

Figure 2. Corresponcence analysis 


\section{Conclusion}

Despite the significant strides made by the Ecuadorian government in the past decade in matters pertaining to social development and education, there are still deficiencies in both areas, particularly in the indigenous communities as the social profiles in this study indicate. These shortcomings are also evident in the mortality rate (Stefos, 2015), gender relations, the level of education and the interrelation of the variables studied, including age, territory, activity status and level of satisfaction with employment. In conclusion it can be said that the indigenous communities in Ecuador are characterized by the following traits:

- Almost half of the population is under the age of 20 and resides principally in the rural areas: the mountainous region and the Amazon.

- Forty percent have some sort of qualification in basic education and $24.42 \%$ in primary education. However, only $2.8 \%$ have an advanced or university degree and as few as $0.12 \%$ have gone on to post graduate studies.

- A third of the indigenous population is bilingual (an indigenous language and Spanish), however, $28.57 \%$ speak only Spanish.

- A third of the indigenous population are students although a little less than $60 \%$ of the population do not find any of the categories (landlord, pensioner, student, housewife, disabled and other) applicable to their status.

- Almost $70 \%$ do not own a cellular phone and only a little more than $30 \%$ have accessed the Internet in the past 12 months.

- A third of the population work in the primary sector (agriculture, livestock farming, hunting, forestry or fishing), nevertheless, $48.15 \%$ correspond to the category of «not applicable».

- More than half of the population (55.24\%) are considered to be poor compared to $43.96 \%$ who are not.

According to data from the National Survey of 2006 Employment, Unemployment and Underemployment of Ecuador (ENEMDU), $67.02 \%$ of the indigenous population of Ecuador was classifiable as poor and $39.72 \%$ as indigent (INEC, 2006). However, according to the ENEMDU survey of 2015, the percentage of poor indigenous people fell to $55.24 \%$ while that of indigent indigenous Ecuadorians to $32.94 \%$. These percentages indicate that there has been some improvement in the social conditions of the indigenous people of Ecuador, nevertheless, the differences in percentage between the two years (2006 and 2015) which span a period of nine years, signify that the process is slow and that consequently, improvement in both social development and education is necessarily a long term objective.

\section{Acknowledgments}

We would like to express our deepest gratitude to the Faculty of Humanities of the University of the Aegean for donating the statistical software SPAD v.4.5 used in this study.

\section{References}

Athanasiadis, I. (1995). Correspondence Analysis and Hierarchical Classification (pp. 51-56). Athens: New Technologies Editions.

Benzécri, P. (1992). Correspondence Analysis Handbook. New York: Dekker.

Instituto Nacional de Estadística y Censos-INEC. (2006). Encuesta Nacional de Empleo, Desempleo y Subempleo-ENEMDU. Quito, Ecuador.

Instituto Nacional de Estadística y Censos-INEC. (2010). Censo de Población y Vivienda. Quito, Ecuador.

Instituto Nacional de Estadística y Censos-INEC. (2015). Encuesta Nacional de Empleo, Desempleo y Subempleo-ENEMDU, 2015. Quito, Ecuador.

Koulianidi, G., \& Stefos, E. (2015). Consequences of Dietary Habits and Endocrine Disruptors in School Performance of Children Aged 10-12 in Greece. American Journal of Food Science and Nutrition, 2(6), 113-120.

Olivier, M. (2008). The analysis of quantitative data (pp. 86-88). Athens: Topos.

Papapostolou, I., \& Stefos, E. (2013). Qualitative analysis on pedagogical research. Methodological approaches. In I. Papapostolou (Ed.), Educational activities. Teaching Interventions in Secondary Education (pp. 244-251). Rhodes: Evdimos Editions. 
Papapostolou, I., Papapostoulou, K., \& Stefos, E. (2013). Educational Research. In Qualitative to Quantitative analysis (p. 178). Rhodes: Evdimos Editions.

Ponce, J., Loaiza, A., \& Núñez, M. (2003). Un perfil del analfabetismo indígena y afro en el Ecuador: Propuesta de focalización para una campaña de alfabetización. Quito: Sistema Integrado de Indicadores Sociales del Ecuador.

Sarmiento, N. M., Paredes, P. A. M., \& Stefos, E. (2016). Deaths by Suicide in Ecuador: A Quantitative Data Analysis. Review of European Studies, 8(1), 145-156. https://doi.org/10.5539/res.v8n1p145

Stefos, E., \& Efstathiou, I. (2013). Quantitative analysis of the data of the School of Trianta during the period of 1906-1916. In I. Papapostolou (Ed.), Educational activities. Teaching Interventions in Secondary Education (pp. 29-57). Rhodes: Evdimos Editions.

Stefos, E., \& Koulianidi, G. (2016). Nutrition Data Analysis Using R: Applications in Higher Education. Health Sciences Research, 3(1), 10-16.

Stefos, E., \& Papapostolou, I. (2013). Research Methodology. Processes and suggestions (p. 406). Rhodes: Evdimos Editions.

Stefos, E. (2015). Causes of Death of Indigenous Ecuadorians. International Journal of Clinical Medicine Research, 2(6), 65-70.

Stefos, E., Athanasiadis, I., Gialamas, B., \& Tsolakidis, C. (2011). The Use of New Technologies and the Project Method in Teaching Statistics: A Case Study in Higher Education. HMS i JME, 3, 84-100.

Torres, R. M. (2005). Analfabetismo y alfabetización en el Ecuador: Opciones para la política y la práctica. Instituto Fronesis.

\section{Copyrights}

Copyright for this article is retained by the author(s), with first publication rights granted to the journal.

This is an open-access article distributed under the terms and conditions of the Creative Commons Attribution license (http://creativecommons.org/licenses/by/4.0/). 